\title{
ANALISIS PERLAKUAN AKUNTANSI DAN PELAPORAN PAJAK PERTAMBAHAN NILAI DALAM MENINGKATKAN AKUNTABILITAS PELAPORAN KEUANGAN PADA KSO WILIAM MEGA NUSATAMA
}

\author{
Atika Ningtyas ${ }^{1)}$ Diana Gustinya ${ }^{2)}$ \\ Program Studi Akuntansi Fakultas Ekonomi \\ Universitas Krisnadwipayana \\ atika.ningtyas.jlr@gmail.com ${ }^{1)}$ \\ dianagustinya@gmail.com ${ }^{2}$ )
}

\begin{abstract}
The purpose of this study is to know the analysis of accounting treatment and reporting value added tax and know accounting taxes related value added tax for accountability internal financial report KSO William Mega Nusatama. This research method uses qualitative method which describes accounting process of value added tax in relation to KSO William Mega Nusatama financial report. The result of the research is the company has conducted the procedure of value added tax in accordance with the Law No.42 of 2009, but has not applied value added tax treatment so that internal financial statements of the company can be said not accountable. And the discussion that can be conveyed is the company keeps the receipt of the installment journal from the consumer and acknowledges the VAT output, keeps the journal and acknowledges the Selling Price as a sale, makes a correction journal on the details of the sales repayment, keeps the journal at the time the company makes a contract of cooperation agreement to the vendor and acknowledges the existence value add taxes entries, keeps the journal at the time the company pays the invoice for the contract to the vendor, makes a correction journal on the payment details of the contract and non contract vendor, compares the nominal amount between the vendor payment details and the sales repayment with the input and output recap, value added tax at the end of 2015.
\end{abstract}

Keywords: analysis of accounting treatment, value added tax reporting, accountability of financial reporting. 


\section{PENDAHULUAN}

Perkembangan bisnis properti di Indonesia mengalami kenaikan yang sangat tajam pada dekade terakhir ini. Hal ini dapat dilihat di dalam masyarakat misalnya dengan banyaknya pembangunan perumahan baru termasuk juga apartemen ataupun investor yang membangun villa untuk dijual kembali. Disamping itu komponen penunjang kepemilikan rumah juga semakin mudah dan menjangkau berbagai lapisan masyarakat.. Hampir semua bank besar di indonesia mempunyai produk kredit kepemilikan rumah dengan berbagai variasi pembiayaan.

Perkembangan usaha atau bisnis yang semakin marak dan peredaran uang yang ada dalam bisnis properti ini tentu membuat pemerintah berpikir untuk menarik pajak yang dari sektor ini lebih besar. Beberapa jenis pajak berkaitan erat dengan bisnis properti, yaitu Pajak Penghasilan, Pajak Pertambahan Nilai dan Pajak Penjualan atas Barang Mewah, Pajak Bumi dan Bangunan, Bea Perolehan Hak Atas Tanah dan Bangunan dan Bea Materai. Belum termasuk pajak daerah yang mungkin dikenakan tergantung pada regulasi masing-masing daerah yang berbeda kebijakannya.

Perkembangan bisnis properti di indonesia saat ini bisa dikatakan sangat maju. Hal ini dapat dilihat dari semakin maraknya pembangunan rumah hunian, apartement, villa dan perkantoran. Perkembangan ini juga mendorong tumbuh nya pengembang-pengembang baru. Namun perkembangan bisnis properti ini semakin membuat kompleksnya masalah dalam transaksi yang berkaitan dengan usaha atau bisnis properti. Semakin banyak variasi atau model transaksi yang terjadi sehingga berpengaruh juga terhadap implikasi perpajakannya.

Fokus penelitian ini adalah Pajak Pertambahan Nilai pada KSO William Mega Nusatama. KSO William Mega Nusatama merupakan suatu kerjasama operasional antara PT Mega Nusatama dengan Bapak William Ponik Phon selaku Komisaris Utama yang menjalankan proyek bernuansa villa residence bernama "The Ribezzi" di Nusa Dua, Bali. Dengan konsep terasering area menghadap ke lepas pantai pandawa, "The Ribezzi" mempunyai 31 unit villa yang diantaranya siap untuk dijual maupun disewakan dengan type sinfonia, fantasia, dan penthouse.

Ditinjau dari kegiatan usahanya, KSO William Mega Nusatama melakukan kegiatan perdagangan villa "The Ribezzi" yang telah dikukuhkan sebagai Pengusaha Kena Pajak pada tanggal 7 Juli 2014 dan dikenakan PPN dikarenakan omsetnya sudah melebih dari Rp 4.800.000.000 setahun menurut Peraturan Menteri Keuangan (PMK) No. 197/PMK.03/2013. Diperkuat juga dengan dokumen administratif berupa Surat Pengukuhan Pengusaha Kena Pajak, Faktur Pajak, Surat Setoran Pajak, Surat Pemberitahuan Tahunan, hingga Bukti Lapor dari Kantor Pelayanan Pajak.

Dilihat dari segi pencatatan laporan keuangan, KSO William Mega Nusatama mempunyai dua laporan keuangan yaitu laporan keuangan inten dan laporan keuangan ekstern atau pajak. Didalam laporan keuangan intern, KSO William Mega Nusatama belum menerapkan perlakuan akuntansi pajak pertambahan nilai (PPN). Namun perusahaan tetap dapat membayar dan melaporkan pajak termasuk PPN dikarenakan adanya pihak konsultan dari luar perusahaan atau pihak ekstern yang membatu menghitungkan hingga melaporkan pajaknya hingga membuat laporan keuangan ekstern yang didalamnya telah diterapkan perlakuan akuntansi pajak pertambahan nilai tanpa memberi tahu perlakuan akuntansi pajak pertambahan nilai yang benar dalam laporan keuangan intern sehingga laporan keuangan intern dapat dikatakan tidak akuntabel.

Ada beberapa permasalahan yang timbul dari Analisis perlakuan akuntansi dan pelaporan pajak pertambahan nilai dalam meningkatkan akuntabilitas pelaporan keuangan, antara lain :

1. Perlakuan akuntansi dan pelaporan pajak pertambahan nilai.

2. Perlakuan akuntansi perpajakan terkait pajak pertambahan nilai diterapkan untuk akuntabilitas laporan keuangan internal.

\section{TINJAUAN PUSTAKA}

Pengertian Pajak merupakan iuran kepada negara (yang dapat dipaksakan) yang terutang oleh yang wajib membayarnya menurut peraturan-peraturan, dengan tidak mendapat prestasi kembali, yang langsung dapat ditunjuk, dan yang gunanya adalah untuk membiayai pengeluaran-pengeluaran umum berhubung 
dengan tugas negara yang menyelenggarakan pemerintahan (Waluyo, 2013:2). Pajak merupakan sumber penerimaan dalam negeri yang merupakan andalan penerimaan negara (Raja Abdurrahman, 2014:1).

Untuk lebih meningkatkan penerimaan di bidang perpajakan, telah beberapa kali dilakukan penyempurnaan, penambahan, bahkan perubahan di bidang perpajakan. Adapun Pajak juga merupakan suatu kewajiban yang harus dibayar oleh masyarakat baik pribadi maupun badan juga termasuk salah satu sumber pembangunan, tak terkecuali pajak pertambahan nilai dan pajak penjualan atas barang mewah.

Pajak Pertambahan Nilai atau Value Added Tax (VAT) atau taxe sur la valeur ajoutee pertama kali diintrodusir di Prancis pada tahun 1954 dan dengan berbagai kelebihankelebihannya, konsep ini diadopsi oleh banyak negara. Namun dalam implementasinya disetiap negara terjadi perkembangan yang berbeda-beda, antara lain karena faktor bahasa. Akibatnya seperti kata Tai, meski VAT telah diadopsi secara cepat dan menyebar ke berbagai negara, namun tidak ada fenomena yang pararel (unparalleled tax phenomenon)".

Pajak Pertambahan Nilai pada dasarnya merupakan pajak penjualan yang dipungut atas dasar nilai tambah yang timbul pada semua jalur produksi dan distribusi (Haula Rosdiana dan Edi Slamet Irianto, 2012:222).

Yang dimaksud dengan nilai tambah adalah semua faktor produksi yang timbul di setiap jalur peredaran suatu barang seperti bunga, sewa, upah kerja, termasuk semua biaya untuk mendapatkan laba. Pada setiap tahap produksi nilai produk dan harga jual produk selalu terdapat nilai, antara lain yang utama karena setiap penjual menginginkan adanya keuntungan sehingga dalam menentukan harga jual, harga perolehan ditambah dengan laba bruto (mark up).

Pajak Pertambahan Nilai adalah pajak yang dikenakan atas konsumsi Barang Kena Pajak atau Jasa Kena Pajak di dalam Daerah Pabean. Orang Pribadi, perusahaan, maupun pemerintah yang mengkonsumsi Barang Kena Pajak atau Jasa Kena Pajak dikenakan PPN (Anastasia Diana dan Lilis Setiawati, 2013:3).

Pada dasarnya, setiap barang dan jasa adalah Barang Kena Pajak atau Jasa Kena Pajak, kecuali ditentukan lain oleh Undang-undang PPN.
Pengusaha kena pajak (PKP) adalah pengusaha yang melakukan penyerahan barang kena pajak (BKP) dan atau penyerahan jasa kena pajak (JKP) yang dikenai pajak berdasarkan Undang-undang Pajak Pertambahan Nilai 1984 dan perubahannya.

Pajak Pertambahan Nilai menurut Direktorat Jendral Pajak, (2013:4) adalah pajak yang dikenakan atas :

1. penyerahan Barang Kena Pajak di dalam Daerah Pabean yang dilakukan oleh pengusaha;

2. impor Barang Kena Pajak;

3. penyerahan Jasa Kena Pajak di dalam Daerah Pabean yang dilakukan oleh pengusaha;

4. pemanfaatan Barang Kena Pajak Tidak Berwujud dari luar Daerah Pabean di dalam Daerah Pabean;

5. pemanfaatan Jasa Kena Pajak dari luar Daerah Pabean di dalam Daerah Pabean;

6. ekspor Barang Kena Pajak Berwujud oleh Pengusaha Kena Pajak;

7. ekspor Barang Kena Pajak Tidak Berwujud oleh Pengusaha Kena Pajak; dan

8. ekspor Jasa Kena Pajak oleh Pengusaha Kena Pajak.

Adapun subjek pajak pertambahan nilai adalah :

1. Pengusaha

Adalah orang pribadi atau badan dalam bentuk apapun yang dalam kegiatan usaha atau pekerjaannya menghasilkan barang, mengimpor barang, mengekspor barang, melakukan usaha perdagangan, memanfaatkan barang tidak berwujud dari luar daerah pabean, melakukan usaha jasa termasuk mengekspor jasa, atau memanfaatkan jasa dari luar daerah pabean.
A. Pengusaha Kena Pajak (PKP)
B. Pengusaha Kecil
C. PMPKP

2. Pemungut PPN

Adalah bendahara pemerintah, badan usaha milik negara, kontraktor perjanjian kerjasama pengusaha pertambangan minyak dan gas, badan, atau instansi pemerintah yang ditunjuk oleh Menteri Keuangan untuk memungut, menyetor, dan melaporkan pajak yang terutang oleh Pengusaha Kena Pajak atas penyerahan JKP kepada bendahara pemerintah, badan, atau instansi pemerintah 
tersebut. (Jeni Susyanti dan Ahmad Dahlan, 2016:172).

Obyek PPN dan PPNBM perusahaan yang bergerak dibidang jasa konstruksi yang pokok adalah penjualan atas jasa pelayanan perencanaan, pelaksanaan, dan pengawasan konstruksi atau konstruksi terintegrasi (PPN keluaran) dan PPN serta PPNBM atas pembelian barang modal material bangunan dan jasa sub kontraktor. Perusahaan jasa konstruksi membeli barang modal yang akan digunakan melaksanakan pekerjaan jasa konstruksi. Barang modal tersebut terutang PPN 10\% (Joseph Purwono, 2012:28).

Dasar hukum tentang PPN DAN PPN BM diatur dalam Undang-undang No.8 tahun 1983, sebagaimana telah beberapa kali diubah dengan Undang-undang No.42 tahun 2009 (Oyok Abunyamin Bin H. Abas, 2015:347).

Atas kegiatan membangun sendiri terutang pajak pertambahan nilai adalah kegiatan membangun bangunan yang dilakukan tidak dalam kegiatan usaha atau pekerjaan oleh orang pribadi atau badan yang hasilnya digunakan sendiri atau digunakan pihak lain (Mardiasmo 2016:358).

Yang dimaksud dengan bangunan adalah berupa satu atau lebih konstruksi teknik yang ditanam atau dilekatkan secara tetap pada satu kesatuan tanah dan atau perairan dengan kriteria :

1. Konstruksi utamanya terdiri dari kayu, beton, pasangan batu bara atau bahan sejenis dan atau baja;

2. Diperuntukkan bagi tempat tinggal atau tempat kegiatan usaha;

3. Luas kesuluruhan paling sedikit $200 \mathrm{~m}^{2}$ (dua ratus meter persegi).

Kegiatan membangun sendiri di kawasan Real Estate yaitu :

1. Kegiatan membangun sendiri yang dilakukan di dalam kawasan real estate oleh pemilik kaveling berlaku ketentuan pengenaan PPN seperti disebutkan sebelumnya $(10 \%$ dikalikan DPP untuk setiap bulan)

2. Pada saat ditandatatanganinya Surat Pemesanan Tanah atau Surat Perjanjian Pra Jual Beli atau Akta Jual Beli atas transaksi penjualan kavling, pembeli tanah kavling wajib mengisi dan menandatangani formulir Surat Pernyataan Kesanggupan membayar Pajak Pertambahan Nilai atas kegiatan membangun sendiri yang diberikan oleh pihak real estate dengan bentuk formulir yang ditetapkan oleh Direktur Jenderal Pajak.

3. Pengusaha real estate wajib melaporkan transaksi penjualan tanah kavling kepada Kepala KPP yang wilayah kerjanya meliputi tempat tanah kavling berada dengan mengirimkan tembusan formulir yang ditetapkan oleh Direktur Jenderal Pajak paling lambat satu bulan sejak tanggal penandatanganan formulir.

4. Apabila pengusaha real estate tidak melakukan kewajiban tersebut, kegiatan pendirian bangunan di atas tanah kavling tersebut dianggap dilakukan oleh pengusaha real estate. (Siti Resmi, 2012:87).

Dalam perjanjian kerja dengan pelanggan (pemilik proyek) diatur bahwa semua transaksi penyerahan Barang Kena Pajak dan atau Jasa Kena Pajak kepada Pelanggan (pemilik proyek) dilakukan atas nama Kerjasama Operasi atau Joint Operation (Chairil Anwar Pohan, 2016:71). Berdasarkan hal tersebut :

1. Joint Operation wajib dikukuhkan sebagai Pengusaha Kena Pajak

2. Atas penyerahan Barang Kena Pajak dan atau Jasa Kena Pajak kepada pelanggan (pemilik proyek), joint operation wajib menerbitkan Faktur Pajak

3. Apabila dalam rangka joint operation tersebut, PT ABC atau PT DEF atas nama joint operation melakukan penyerahan langsung kepada pelanggan (pemilik proyek), maka penyerahan tersebut dianggap sebagai penyerahan dari PT ABC atau PT DEF kepada joint operation, sehingga $\mathrm{PT}$ ABC atau PT DEF harus membuat Faktur Pajak kepada joint operation dan joint operation membuat Faktur Pajak kepada pelanggan (pemilik proyek).

Pengusaha Kena Pajak adalah pengusaha yang melakukan penyerahan Barang Kena Pajak dan atau penyerahan Jasa Kena Pajak yang dikenai pajak berdasarkan Undang Undang Pajak Pertambahan Nilai Barang dan Jasa dan Pajak Penjualan Barang Mewah (Direktorat Jendral Pajak, 2013:5).

PPN memiliki peranan strategis dan signifikan dalam posisi penerimanaan negara dari sektor perpajakkan. Oleh karena itu para pengusaha di Indonesia wajib melaporkan usahanya agar segera dikukuhkan sebagai 
Pengusaha Kena Pajak (PKP). Kewajiban melaporkan usaha tersebut harus dilakukan paling lama akhir bulan berikutnya setelah bulan terjadinya jumlah penjualan barang atau jasa kena pajak melebihi Rp. 4.800.000.000 sesuai ketentuan PMK No.197/PMK.03/2013. Jika pengusaha tidak dapat mencapainya, maka pengusaha dapat langsung mencabut permohonan pengukuhan sebagai PKP.

Pengusaha Kena Pajak adalah orang atau badan dalam bentuk apapun yang dalam lingkungan perusahaan atau pekerjaannya menghasilkan barang, mengimpor, mengekspor barang, melakukan usaha perdagangan atau melakukan usaha (Dwi Sunar Prasetyono,2012:220).

Sedangkan Anastasia Diana dan Lilis Setiawati (2014:334) menyatakan bahwa, Pengusaha yang melakukan penyerahan Barang Kena Pajak dan atau Jasa Kena Pajak di dalam Daerah Pabean, melakukan ekspor Barang Kena Pajak Berwujud dan atau Barang Kena Pajak Tidak Berwujud dan melakukan ekspor Jasa Kena Pajak, kecuali pengusaha kecil, diwajibkan

1. Melaporkan usahanya untuk dikukuhkan sebagai Pengusaha Kena Pajak

2. Memungut pajak yang terutang

3. Menyetorkan PPN yang masih harus dibayar dalam hal Pajak Keluaran lebih besar daripada Pajak Masukan yang dapat dikreditkan, serta

4. Melaporkan penghitungan pajak.

Pengusaha kecil dapat memilih untuk dikukuhkan sebagai Pengusaha Kena Pajak, Pengusaha kecil yang memilih untuk dikukuhkan sebagai Pengusaha Kena Pajak wajib memungut, menyetor, dan melaporkan PPN dan PPNBM yang terutang. Pengusaha kecil adalah pengusaha yang selama satu tahun buku melakukan penyerahan Barang Kena Pajak dan atau Jasa Kena Pajak dengan jumlah perederan bruto dan atau penerimaan bruto tidak lebih dari Rp. 600.000.000,-.

Nomor Pokok Wajib Pajak adalah merupakan suatu sarana dalam administrasi perpajakan yang dipergunakan sebagai tanda pengenal diri atau identitas Wajib Pajak (Siti Resmi, 2016:23).

Setiap Wajib Pajak hanya diberikan satu NPWP. Nomor Pokok Wajib Pajak juga dipergunakan untuk menjaga ketertiban dalam pembayaran pajak dan dalam pengawasan administrasi perpajakan. Dengan memiliki NPWP, Wajib Pajak memperoleh beberapa manfaat langsung lainnya seperti seebagai pembayaran pajak dimuka (angsuran atau kredit pajak) atas Fiskal Luar Negeri yang dibayar sewaktu Wajib Pajak bertolak ke Luar Negeri sebagai persyararatan ketika melakukan pengurusan Surat Izin Usaha Perdagangan (SIUP) dan sebagai salah satu syarat pembuatan Rekening Koran di bank. Terhadap Wajib Pajak yang tidak mendaftarkan diri untuk mendapatkan Nomor Pokok Wajib Pajak dikenakan sanksi sesuai dengan ketentuan peraturan perundangundangan perpajakan.

Faktur Pajak adalah bukti pungutan pajak yang dibuat oleh Pengusaha Kena Pajak (PKP) yang melakukan penyerahan Barang Kena Pajak (BKP) atau penyerahan Jasa Kena Pajak (JKP). Apabila terjadi penyerahan BKP dan atau JKP, maka PKP yang menyerahkan BKP dan atau JKP tersebut wajib memungut Pajak Pertambahan Nilai (PPN) yang terutang dan memberikan faktur pajak sebagai bukti pungutan pajak (TMBooks, 2015:350).

Ketentuan mengenai kewajiban penerbitan faktur pajak tersebut tidak berlaku untuk pemakaian sendiri BKP dan atau JKP untuk tujuan produktif yang tidak dipungut PPN. Faktur pajak tidak perlu dibuat secara khusus atau berbeda dengan faktur penjualan. Faktur pajak dapat berupa faktur penjulan atau dokumen tertentu yang ditetapkan sebagai faktur pajak oleh Dirjen Pajak.

Orang pribadi atau badan yang tidak dikukuhkan sebagai PKP dilarang membuat faktur pajak". Jadi faktur pajak hanya boleh dibuat oleh PKP untuk melindungi pembeli dari pemungutan pajak yang tidak semestinya. Faktur pajak dibuat paling sedikit dua rangkap yang peruntukannya adalah sebagai berikut :

1. Lembar ke-1, disampaikan kepada pembeli BKP atau penerima JKP.

2. Lembar ke-2, untuk arsip PKP yang menerbitkan faktur pajak.

Apabila faktur pajak dibuat lebih dari dua lembar, maka harus dinyatakan secara jelas peruntukannya dalam lembar faktur pajak yang bersangkutan. PKP harus membuat faktur pajak dengan menggunakan Kode dan Nomor Seri Faktur Pajak yang penomorannya dilakukan 
secara sentralisasi oleh Direktorat Jendral Pajak. Kode dan Nomor Seri Faktur Pajak tersebut terdiri dari enam belas digit yaitu :

1. 2 digit Kode Transaksi;

2. 1 digit Kode Status;

3. 13 digit Nomor Seri Faktur Pajak yang ditentukan oleh Direktorat Jenderal Pajak.

Tarif Pajak adalah ketentuan presentase (\%) atau jumlah (rupiah) pajak yang harus dibayar oleh Wajib Pajak sesuai dengan dasar pajak atau objek pajak (Rismawati Sudirman dan Antong Amiruddin, 2012:9).

Sedangkan Direktorat Jendral Pajak (2013:12) menyatakan bahwa, "Tarif PPN \& PPNBM adalah:

1. Tarif PPN adalah $10 \%$ (sepuluh persen)

2. Tarif PPN sebesar $10 \%$ (sepuluh persen) diterapkan atas :

- Ekspor Barang Kena Pajak (BKP)

Berwujud;

- Ekspor BKP tidak berwujud;

- Ekspor Jasa Kena Pajak (JKP).

3. Tarif PPNBM adalah paling rendah $10 \%$ (sepuluh persen) dan paling tinggi 200\% (dua ratus persen)

4. Tarif PPNBM atas ekspor BKP tergolong mewah adalah $0 \%$ (nol persen).

Dasar Pengenaan Pajak adalah nilai berupa uang yang dijadikan dasar untuk menghitung pajak yang terutang (Neneng Hartati 2015:241). Kemudian Thomas Sumarsan (2017:398) berpendapat bahwa, pajak nilai yang terutang dihitung dengan cara mengalikan tarif di atas dengan Dasar Pengenaan Pajak atau DPP yang meliputi harga jual, penggantian, nilai impor, nilai ekspor, atau nilai lain.

Mekanisme Perhitungan Pajak Pertambahan Kena Pajak menurut Ikatan Akuntan Indonesia (2013:291) adalah Setiap Pengusaha Kena Pajak yang menyerahkan Barang Kena Pajak dan atau Jasa Kena Pajak diwajibkan membuat Faktur Pajak untuk memungut pajak yang terutang".

Pajak yang dipungut ini dinamakan Pajak Keluaran (output tax). Hal ini sesuai dengan basis akrual (accrual basic) yang digunakan oleh UU PPN 1984. Pada saat Pengusaha Kena Pajak tersebut di atas membeli Barang Kena Pajak dan atau menerima Jasa Kena Pajak dari Pengusaha Kena Pajak lain, juga membayar pajak yang terutang, yang dinamakan Pajak Masukan (input $\operatorname{tax})$.
Setiap Pengusaha Kena Pajak diwajibkan untuk melaporkan pemungutan dan pembayaran pajak yang terutang kepada Kepala Kantor Pelayanan Pajak setempat paling lama akhir bulan berikutnya setelah berakhirnya Masa Pajak. Kemudian Wirawan B. Ilyas dan Rudy Suhartono (2013:240) menyatakan untuk menghitung Pajak Pertambahan Nilai, harus mengetahui:

1. Transaksi yang terutang PPN dan jenis Barang Kena Pajak / Jasa Kena Pajak sebagai dasar terutang atau tidaknya PPN atas transaksi tersebut,

2. Tarif dan dasar pengenaan PPN untuk menghitung besarnya PPN yang terutang

3. Saat, syarat dan bentuk Faktur Pajak sebagai bukti pemungutan PPN pada saat penyerahan (Pajak Keluaran) dan juga sebagai bukti pengkreditan Pajak Masukan (PPN atas perolehan),

4. Saat dan syarat pengkreditan Pajak Masukan untuk diperhitugkan dengan Pajak Keluaran dalam tiap-tiap bulan / masa pajak. Akibat pengkreditan tersebut menyebabkan adanya PPN yang kurang atau lebih dibayar".

Dwi Sunar Prasetyono (2012:118) menyatakan bahwa, berkaitan dengan cara kerja sistem PPN, ada beberapa hal yang mesti dipahami, diantaranya sebagai berikut:

1. Sistem pemungutan PPN. Dalam sistem pajak pertambahan nilai, pajak dipungut secara bertingkat pada jalur produksi dan distribusi dengan tidak ada unsur pemungutan pajak berganda.

2. Mekanisme kredit pajak. Hal ini dimungkinkan dengan adanya mekanisme kredit pajak dari tarif pajak yang sama, yaitu $10 \%$ (sepuluh persen). Seorang pengusaha kena pajak akan dipungut PPN dari barang dan jasa yang dibeli atau diperoleh untuk keperluan usahanya.

3. Pajak masukan. Barang jasa yang dibeli atau diperoleh pengusaha tersebut merupakan "masukan" (input) untuk keperluan usahanya, dan pajak yang telah dibayar pada saat pembelian atau perolehan barang atau jasa tersebut dinamakan pajak masukan. Apabila pengusaha kena pajak tersebut menjual barang atau menyerahkan jasa untuk langganannya, maka ia akan memungut pajak pertambahan nilai. 
4. Pajak keluaran. Barang atau jasa yang diserahkan oleh pengusaha kena pajak tersebut merupakan "keluaran" (output) dan PPN yang dipungutnya merupakan pajak keluaran.

Pajak Keluaran adalah pajak pertambahan nilai terutang yang wajib dipungut oleh pengusaha kena pajak yang melakukan penyerahan barang kena pajak, penyerahan jasa kena pajak, ekspor barang kena pajak berwujud, ekspor barang kena pajak tidak berwujud dan atau ekspor jasa kena pajak ( Sugeng Wahono, 2012:305). Pada saat menjual barang maka disebut pajak keluaran sebesar $10 \%$ dari DPP, dan setiap pengusaha kena pajak yang melakukan penyerahan $\mathrm{BKP} / \mathrm{JKP}$ harus memungut pajak keluaran kepada pembeli.

Pajak Masukan (PM) adalah pajak pertambahan nilai yang seharusnya sudah dibayar oleh pengusaha kena pajak karena perolehan barang kena pajak dan atau perolehan jasa kena pajak dan atau pemanfaatan barang kena pajak tidak berwujud dari luar daerah pabean dan atau pemanfaatan jasa kena pajak dari luar daerah pabean dan atau impor barang kena pajak (Pasal 1 UU No.42 tahun 2009). Pada saat membeli barang disebut pajak masukan sebesar $10 \%$ dari DPP. Pajak yang harus dibayar adalah PK - PM yaitu jumlah pajak keluaran dikurangi pajak masukan dalam bulan tersebut atau disebut pengkreditan pajak masukan. Kemudian Hery, S.E., M.Si, (2014:247) menyatakan bahwa untuk pajak masukan yang dikreditkan pada masa pajak berikutnya, batas akhir pengkreditan adalah 3(tiga) bulan setelah masa pajak berakhir (sepanjang belum dibebankan sebagai biaya atau pun tidak ditambahkan atau dikapitalisasike dalam harga perolehan BKP atau JKP, dan belum dilakukan pemeriksaan). Pengkreditan pajak masukan pada masa pajak berikutnya in mungkin terjadi karena adanya keterlambatan dalam hal penerimaan faktur pajak.

Seluruh pajak masukan dan pajak keluaran selama satu bulan haruslah diaporkan dalam SPT masa PPN (termasuk juga jika besarnya pajak masukan sama dengan pajak keluaran). Dengan kata lain, penyampaian SPT masa PPN wajib dilakukan oleh PKP, baik kondisi kurang bayar, lebih bayar atau pun nihil.

1. Dalam satu, jika total jumlah pajak keluaran lebih besar dibanding dengan total jumlah pajak masukan, maka PKP harus menyetorkan selisihnya tersebut (kurang bayar) ke kas negara (melalui bank persepsi atau kantor pos) dengan menggunakan Surat Setoran Pajak (SSP) paling lambat akhir bulan berikutnya setelah berakhirnya masa pajak dan sebelum SPT masa PPN disampaikan. Sedangkan pelaporannya disampaikan paling lambat akhir bulan berikutnya setelah berakhirnya masa pajak.

2. Sebaliknya, jika total jumlah pajak keluaran lebih kecil dibanding dengan total jumlah pajak masukan, maka akan terjadi lebih baya. Dalam hal ini, PKP bisa memperhitungkan kelebihan bayar tersebut pada masa pajak berikutnya (yang dikenal dengan sebutan kompensasi) sesuai dengan pasal 9 ayat (4) Undang Undang PPN dan PPnBM nomor 42 tahun 2009, atau bisa juga mengajukan permohonan pengembalian kelebihan bayar tersebut pada bulan terakhir dari tahun pajak bersangkutan (yang dikenal dengan sebutan restitusi) sesuai dengan Pasal 9 ayat (4a) Undang-Undang PPN dan PPnBM nomor 42 tahun 2009.

Pengertian Akuntansi menurut Hery (2017:1):

1. Terjemahan APB Statement, Akuntansi merupakan sebuah aktifitas jasa, dimana fungsinya adalah memberikan informasi kuantitatif, terutama informasi mengenai keuangan dan entitas ekonomi, yang dimaksudkan akan menjadi berguna dalam pengambilan keputusan eekonomi (dalam membuat pilihan diantara berbagai alternative yang ada".

2. Terjemahan A Statement of Basic Accounting Theory (ASOBAT), Akuntansi adalah proses mengidentifikasi, mengukur, dan menyampaikan informasi ekonomi bagi para penggunannya dalam mempertimbangkan berbagai alternatif yang ada dan membuat kesimpulan".

3. Terjemahan American Institut of Certified Public Accountants (AICPA). Akuntansi adalah seni pencatatan, pengklasifikasian dan pengikhtisaran transaksi dan peristiwa keuangan dengan cara tertentu dan dalam ukuran moneter, termasuk penafsiran dan hasil-hasilnya".

Akuntansi adalah proses data transaksi yang dibuktikan dengan faktur, lalu dari transaksi 
dibuat jurnal, buku besar, neraca lajur, kemudian akan menghasilkan informasi dalam bentuk laporan keuangan yang digunakan pihak-pihak tertentu ( Wiratna Sujarweni, 2015:3). Akuntansi Pajak merupakan bagian dari akuntansi yang timbul dari unsur spesialisasi yang menuntut keahlian dalam bidang tertentu (Sukrisno Agoes dan Estralita Trisnawati (2013:10).

Akuntansi pajak tercipta karena adanya suatu prinsip yang diatur dalam UU perpajakan dan pembentukannya terpengaruh oleh fungsi perpajakan dalam mengimplementasikan sebagai kebijakan pemerintah. Tujuan dari akuntansi pajak adalah menetapkan besarnya pajak terutang berdasarkan laporan keuangan yang disusun oleh perusahaan. Wirawan B. Ilyas dan Diaz Priantara (2015:2), Perpajakan tidak akan lepas dari akuntansi keuangan karena akuntabilitas penghitungan dan pelaporan pajak dalam Surat Pemberitahuan (SPT) membutuhkan keterandalan data, catatan, dan laporan akuntansi keuangan. Data, catatan dan laporan akuntansi keuangan tersebut berisikan transaksi-transaksi ekonomi yang dicatat karena telah memenuhi syarat pengakuan dan nilai yang akan dicatat diukur. Profesional di bidang perpajakan baik dalam posisinya sebagai pegawai Direktorat Jenderal Pajak (DJP) atau Wajib Pajak (WP) membutuhkan akuntabilitas akuntansi tersebut. Bahkan untuk WP yang tidak wajib pembukuan (akuntansi) tetap wajib membuat pencatatan atau pembukuan dan akuntansi keuangan menjadi penting dan harus diselenggarakan oleh WP.

Sebaliknya profesional di bidang akuntansi keuangan harus mempertimbangkan implikasi transaksi ekonomi bahkan rencana korporasi kepada beban pajak dan pembayaran pajak. Contoh penjualan atau pembelian barang dan atau jasa tidak dapat mengabaikan PPN atau PPNBM, pembayaran gaji atau sewa tidak dapat mengabaikan PPh pasal 21, 23, atau 26. Hal ini disebut sebagai manajemen dan perencanaan pajak. Oleh karena itu akntansi keuangan sebaiknya tidak dibahas sendiri melainkan mengkaitkannya dengan aspek perpajakan. Dengan kata lain transaksi ekonomis dilihat secara integratif antara akuntansi dengan pajaknya. Dengan demikian, Laporan Keuangan adalah suatu penyajian yang terstruktur tentang informas posisi keuangan, arus kas, dan kinerja keuangan suatu entitas yang bermanfaat bagi sebagian besar kalangan pengguna laporan keuangan dalam membuat keputusan ekonomi.

Tahapan atau siklus akuntansi pajak pada dasarnya sama dengan akuntansi keuangan atau akuntansi komersial, yaitu :

1. Identifikasi transaksi keuangan atau ekonomi yang berimplikasi kepada perpajakan

2. Pencatatan atau perekaman transaksi ke dalam program aplikasi keuangan

3. Penyetoran pajak ke kas negara melalui bank resepsi

4. Pelaporan pajak ke KPP

5. Administrasi dokumen pajak".

Sukrisno Agoes dan Estralita Trisnawati (2013:13) menyatakan bahwa Nama-nama akun pada laporan keuangan yang berkaitan dengan akuntansi pajak adalah sebagai berikut :

1.Neraca - Sisi Aset

Pajak dibayar dimuka ( Prepaid Tax)

Pajak dibayar dimuka biasa disajikan

sebagai biaya dibayar dimuka ( prepaid expense ) dalam aset lancar. Pajak dibayar dimuka dapat terdiri dari:

A. PPh 22, PPh 23, PPh 24, PPh 25, dan PPh 28A (bila ada)

B. PPh atas pengalihan hak atas tanah dan bangunan

C. Pajak Masukan

2. Neraca-Sisi Kewajiban

Utang Pajak ( Tax Payable ) tediri dari :

A. $\mathrm{PPh}$ 21, $\mathrm{PPh} 23, \mathrm{PPh} 26, \mathrm{PPh} 29$

B. Pajak Keluaran

3. Laba Rugi

A. Beban Pajak penghasilan (Income Tax Expense)

B. PBB, Pajak Masukan yang tidak dapat dikreditkan, dan Bea Materai dicatat sebagai beban operasional (operatioan expense).

Penelitian Kualitatif merupakan penelitian khusus objek yang tidak dapat diteliti secara statistik atau cara kuantifikasi (M. Djunaidi Ghony dan Fauzan Almanshur 2016:13). Penelitian kualitatif biasanya digunakan melalui peristiwa sosial, gejala ruhani, dan proses tanda berdasarkan nonpositivis. Misalnya kehidupan masyarakat, sejarah, tingkah laku, fungsionalisasi organisasi, gerakan sosial, keagamaan, atau hubungan kekerabatan. Penelitian kualitatif menghasilkan data deskriptif berupa ucapan, tulisan dan perilaku orang-orang yang diamati. 
Melalui penelitian kualitatif, peneliti dapat mengenali subjek dan merasakan pengalaman mereka dalam kehidupan sehari-hari.

Analisis data merupakan suatu pencarian pola-pola dalam data, yaitu perilaku yang muncul, objek-objek. Atau badan pengetahuan ( a body of knowledge ) (Rutam Ahmadi, 2016:229). Analisis data pada penelitian kuantitatif dan kualitatif sangat berbeda. Pada penelitian kuantitatif, analisis data biasanya dilakukan dengan menggunakan statistik dan dilakukan apabila seluruh data sudah terkumpul serta biasanya dilaksanakan pada akhir penelitian (pengumpulan data). Analisis data penelitian kuantitatif dapat dilakukan siapa pun asalkan ia atau mereka menguasai statistik walaupun tidak pernah ikut dalam proses penelitian.

\section{METODE PENELITIAN}

Pendekatan penelitian menggunakan metode kualitatif yaitu dengan menerapkan secara langsung perlakuan akuntansi dan pelaporan pajak pertambahan nilai terhadap kesesuaian dengan Akuntansi Perpajakan di dalam laporan keuangan intern Perusahaan.

Populasi dalam penelitian ini berupa data laporan keuangan KSO William Mega Nusatama. Sedangkan sampel dalam penelitian ini adalah neraca dan bukti pendukung kas atau bank masuk dan kas atau bank keluar berupa invoice, kwitansi serta faktur pajak yang dipilih secara random tahun 2014 dan tahun 2015.

Pengumpulan data yang dilakukan penulis adalah dengan menggunakan Sumber Data Sekunder yaitu data yang diperoleh dari perusahaan dalam bentuk yang sudah jadi seperti laporan keuangan dalam hal ini berupa neraca perusahaan dan data pendukung lainnya. Data sekunder lainnya yaitu data yang diambil dari web dan situs-situs lainnya. Sedangkan metode pengumpulan data dalam penelitian ini dilakukan dengan metode :

1. Metode wawancara yaitu dengan melakukan wawancara dengan pihak intern perusahaan

2. Metode tinjauan kepustakaan (library research) yaitu metode pengumpulan data yang dilakukan dengan mempelajari teoriteori dan konsep-konsep yang berhubungan dengan masalah yang sedang diteliti oleh penulis melalui buku-buku, makalah, jurnal, dan penelitian yang dilakukan oleh penelitian sebelumnya guna memperoleh landasan yang bersifat teoritis.

3. Metode peengumpulan data dengan mengakses web dan situs-situs terkait yang memberikan informasi tentang masalah dalam penelitian ini.

Analisis Data yang dilakukan pada KSO William Mega Nusatama adalah dengan menggunakan metode deskriptif, yang dilakukan dengan cara mengumpulkan, mengolah, dan menginprestasikan data yang diperoleh sehingga memberikan keterangan yang benar dan lengkap untuk pemecahan masalah yang dihadapi. Sedangakan yang melakukan analisis data adalah peneliti yang sejak awal terjun ke lapangan berinteraksi dengan latar dan orang (subjek) dalam rangka pengumpulan data.

Dokumen yang diambil adalah :

1. Rincian uang muka penjualan

2. Rincian pembayaran vendor

3. Rekap pajak pertambahan nilai

4. Faktur Pajak Masukan

5. Faktur Pajak Keluaran

6. Surat Pemberitahuan Tahunan (SPT)

7. Bukti lapor dari KPP

8. Neraca

\section{HASIL DAN PEMBAHASAN Hasil Penelitian}

Dari hasil penelitian, penulis mengambil data tahun 2014 dan 2015. Adapun perusahaan belum melakukan serah terima unit atau belum adanya Akta Jual Beli. Perusahaan mempunyai dua laporan keuangan yaitu laporan keuangan intern yang dibuat oleh karyawan dan laporan keuangan pajak yang dibuat oleh konsultan.

Perusahaan telah melakukan kegiatan perdagangan villa "The Ribezzi" yang dikukuhkan sebagai PKP atau Pengusaha Kena Pajak tanggal 7 Juli 2014 dan dikenakan PPN dikarenakan omsetnya melebihi angka Rp 4.800.000.000 setahun menurut Peraturan Menteri Keuangan No. 197/PMK.03/2013. Diperkuat dengan dokumen administratif perpajakan berupa Surat Pengukuhan PKP, Faktur Pajak Masukan, Faktur Pajak Keluaran, SSP, SPT hingga bukti lapor dari KPP. Berikut adalah data perhitungan pajak pertambahan nilai menurut SPT : 
Perhitungan Pajak Pertambahan Nilai

KSO William Mega Nusatama

Tahun 2014 dan 2015

\section{Nov 2014 PPN Keluaran \\ PPN Masukan \\ (Lebih) / Kurang bayar}

\section{Des-14 PPN Kellaran \\ PPN Masukan}

(Lebih) bayar

Jan-15 PPN Keluaran

PPN Masukan

(Lebih) bayar

Feb-15 PPN Keluaran

PPN Masukan

(Lebih) bayar

Mar-15 PPN Keluaran

PPN Masukan

(Lebih) bayar

Apr-15 PPN Keluaran

PPN Masukan

(Lebih) bayar

pembetulan

Mar-15 PPN Keluaran

PPN Masukan

(Lebih) bayar

Apr-15 PPN Keluaran

PPN Masukan

(Lebih) bayar

(Lebih) bayar - pembetulan
230.992.500

312.931 .041

(81.938.541)

261.812.875

73.871 .817

187.941 .058

(81.938.541)

106.002 .516

215.967.325

290.167 .381

(74.200.056)

(74.200.056)

212.895 .905

(212.895.905)

(74.200.056)

(287.095.961)

367.620 .873

107.709 .527

259.911 .346

(287.095.961)

(27.184.615)

94.733 .752

13.743.227

80.990 .525

(27.184.615)

53.805 .910

378.078 .576

107.709.527

270.369.049

(287.095.961)

(16.726.912)

94.733 .752

13.743.227

80.990 .525

(16.726.912)

64.263.613

53.805 .910
Mei-15 PPN Keluaran

417.140.959

PPN Masukan

103.103.367

(Lebih) bayar

314.037 .593

314.037 .593

Jun-15 PPN Keluaran

PPN Masukan

59.417.128

78.762 .144

(19.345.016)

(Lebih) bayar

Jul-15 PPN Keluaran

PPN Masukan

(Lebih) bayar

Agust-15 PPN Keluaran

PPN Masukan

(Lebih) bayar

Sep-15 PPN Keluaran

PPN Masukan

(Lebih) bayar

Okt-15

PPN Keluaran

PPN Masukan

(Lebih) bayar
$(19.345 .016)$

50.215 .738

137.008 .024

(86.792.286)

(19.345.016)

(106.137.302)

270.337.096

10.746 .134

259.590 .961

(106.137.302)

153.453.659

83.893.109

114.567 .097

(30.673.988)

(30.673.988)

479.461.139

84.101 .380

395.359 .760

(30.673.988)

364.685 .772 
pembetulan

Okt-15

PPN Keluaran

479.461 .139

PPN Masukan

84.101 .380

395.359 .760

(Lebih) bayar

(30.673.988)

(Lebih) bayar - pembetulan

364.685 .772

$\begin{array}{r}8.366 .179 \\ \hline 373.051 .952\end{array}$

Nop-15 PPN Keluaran

71.459 .321

PPN Masukan

245.203 .253

(Lebih) bayar

(173.743.932)

(173.743.932)

Des-15 PPN Keluaran

PPN Masukan

110.332 .503

102.620 .525

7.711 .978

(Lebih) bayar

$\frac{(173.743 .932)}{(166.031 .954)}$

\section{pembetulan}

Des-15 PPN Keluaran

PPN Masukan

110.332 .503

102.620 .525

7.711 .978

(Lebih) bayar

(173.743.932)

(Lebih) bayar - pembetulan

(166.031.954)

$\frac{(49.599 .244)}{(215.631 .198)}$

Oleh karena itu, perusahaan telah melakukan prosedur PPN yang sesuai dengan peraturan Undang Undang No. 42 tahun 2009. Namun belum menerapkan perlakuan akuntansi pajak pertambahan nilai sehingga laporan keuangan internal perusahaan dapat dikatakan tidak akuntabel. Dan masalah yang timbul pada laporan keuangan internal perusahaan adalah :

1. Tidak terdapat akun PPN Keluaran

$\begin{array}{ll} & \text { DATA PENJUALAN } \\ \text { Buyer } & : \text { Alian Fian } \\ \text { Unit } & : \text { Z10 } \\ \text { Harga } & : \text { Rp } 4.375 .350 .000 \\ \text { DPP+PPN } & : \text { Rp } 4.812 .885 .000\end{array}$

Tabel IV - 1

Rincian Cicilan Penjualan unit E4 an Alian Fian KSO William Mega Nusatama Tahun 2014 dan 2015

\begin{tabular}{|c|c|c|c|c|c|c|}
\hline \multirow{2}{*}{ Tanggal } & \multirow{2}{*}{ No Faktur } & \multirow{2}{*}{ Note } & \multicolumn{3}{|c|}{ Pembayaran } & \multirow{2}{*}{ Sisa } \\
\hline & & & DPP & PPN & $\mathrm{DPP}+\mathrm{PPN}$ & \\
\hline 22-Jun-15 & 010.002 .15 .52888844 & Cicilan 1 & $145,845,000$ & $14,584,500$ & $160,429,500$ & $4,652,455,500$ \\
\hline 13-Jul-15 & 010.002 .15 .52888849 & Cicilan 2 & $145,845,000$ & $14,584,500$ & $160,429,500$ & $4,492,026,000$ \\
\hline 19-Aug-15 & 010.002 .15 .52888861 & Cicilan 3 & $145,845,000$ & $14,584,500$ & $160,429,500$ & $4,331,596,500$ \\
\hline 07-Sep-15 & 010.002 .15 .52888866 & Cicilan 4 & $145,845,000$ & $14,584,500$ & $160,429,500$ & $4,171,167,000$ \\
\hline 13-0ct-15 & 010.003 .15 .86606447 & Cicilan 5 & $145,845,000$ & $14,584,500$ & $160,429,500$ & $4,010,737,500$ \\
\hline 04-Nov-15 & 010.003 .15 .86606453 & Cicilan 6 & $145,845,000$ & $14,584,500$ & $160,429,500$ & $3,850,308,000$ \\
\hline 08-Dec-15 & 010.003 .15 .86606458 & Cicilan 7 & $145,845,000$ & $14,584,500$ & $160,429,500$ & $3,689,878,500$ \\
\hline & JUMLAH & & $1,020,915,000$ & $102,091,500$ & $1,123,006,500$ & $3,689,878,500$ \\
\hline
\end{tabular}

Sumber : Data diambil dari Perusahaan (2017)

Pada tanggal 13 Juli 2015, perusahaan menerima cicilan ke 2 Unit E4 a/n Alian Fian.

Jurnalnya :

Bank Victoria KSO Rp 160.429.500

Uang Muka Penjualan Unit B Rp 160.429.500

2. Tidak terdapat akun PPN Masukan

Pada saat perusahaan membuat kontrak perjanjian kerjasama kepada vendor :

Surat Perjanjian Kerjasama Pt Mgm

Rincian Pekerjaan Infrastruktur

SPK 006/SPK/2014JUL01

Tanggal 01 Juli 2014

Total : Rp 5.238.083.528

Jasa Kontraktor 10\% : Rp 523.808.353

DPP

: Rp 5.761.891.881

PPN

: Rp $\quad 576.189 .188$

Total Pekerjaan

: Rp 6.338.081.069

Jurnalnya :

Proyek dlm pelaksanaan Rp 6.338.081.069

Hutang MGM

Rp 6.338.081.069

Pada saat pembayaran kepada vendor : 


\begin{tabular}{|c|c|c|c|c|c|}
\hline TANGGAL & KETERANGAN & $\begin{array}{c}\text { JUMLAH } \\
\text { DIBAYAR }\end{array}$ & $\begin{array}{c}\text { SALDO } \\
\text { HUTANG }\end{array}$ & PPH 4(2) & $\begin{array}{c}\text { JUMLAH } \\
\text { SETOR BANK }\end{array}$ \\
\hline 8-Dec-14 & Tagihan Uang Muka ke 1 & $750,200,000$ & $5,587,881,069$ & $27,280,000$ & $750,200,000$ \\
\hline 8-Dec-14 & Tagihan Uang Muka ke 2 & $550,000,000$ & $5,037,881,069$ & $20,000,000$ & $550,000,000$ \\
\hline 8-Dec-14 & Tagihan Uang Muka ke 3 & $573,259,456$ & $4,464,621,613$ & $20,845,798$ & $573,259,456$ \\
\hline 4-Mar-15 & Tagihan Uang Muka ke 4 & \begin{tabular}{|l|l|}
$517,416,086$ \\
\end{tabular} & $3,947,205,527$ & $18,815,130$ & $517,416,086$ \\
\hline 4-Mar-15 & Tagihan progress $37,886 \%$ & $\begin{array}{l}677,674,407 \\
\end{array}$ & $3,269,531,120$ & $24,642,706$ & $677,674,407$ \\
\hline 4-Mar-15 & Tagihan progress $60,569 \%$ & $\begin{array}{l}1,078,250,088 \\
\end{array}$ & $2,191,281,032$ & $39,209,094$ & $1,078,250,088$ \\
\hline 17-Mar-15 & Tagihan progress $65,56 \%$ & $237,297,731$ & $1,953,983,301$ & $8,629,008$ & $228,668,723$ \\
\hline 28-Apr-15 & Tagihan progress $66,45 \%$ & $91,029,050$ & $1,862,954,251$ & $2,482,609$ & $88,546,440$ \\
\hline 13-Jul-15 & Tagihan progress $67,478 \%$ & $91,125,750$ & $771,828,501$ & $3,313,664$ & $87,812,086$ \\
\hline 3-Sep-15 & Tagihan progress $69,33 \%$ & $128,251,000$ & $1,643,577,501$ & $3,497,755$ & $124,753,245$ \\
\hline \multirow[t]{2}{*}{ 29-Oct-15 } & Tagihan Progress $71,240 \%$ & $178,828,939$ & $1,464,748,562$ & $4,877,153$ & $173,951,786$ \\
\hline & & $4,873,332,507$ & $1,464,748$ & $173,592,918$ & $4,850,532$, \\
\hline
\end{tabular}

Sumber : Data diambil dari perusahaan (2017)

Tanggal 13 Juli 2015 - Tagihan Progress $67,478 \%$ Pekerjaan Infrastruktur,

Jurnalnya :

Hutang MGM - Infrastruktur (d) Rp 91.125.75

Hutang Pajak PPh 4(2)(k) Rp 3.313.664

Bank Victoria KSO (k) Rp 87.812.086

\section{Pembahasan}

Dari hasil penelitian diatas, maka akuntansi perpajakan terkait pajak pertambahan nilai seharusnya sebagai berikut

\section{DATA PENJUALAN}

$\begin{array}{ll}\text { Konsumen } & \text { : Alian Fian } \\ \text { Unit } & : \text { Z10 } \\ \text { DPP } & : \operatorname{Rp~} 4.375 .350 .000 \\ \text { PPN } & : \operatorname{Rp~} 437.535 .000 \\ \text { Penjualan } & : \text { Rp 4.812.885.000 }\end{array}$

\begin{tabular}{|c|c|c|c|c|c|c|}
\hline \multirow[b]{2}{*}{ Tanggal } & \multicolumn{5}{|c|}{$\begin{array}{c}\text { Tabel IV - } 3 \\
\text { Rincian Cicilan Penjualan unit E4 an Alian Fian } \\
\text { KSO William Mega Nusatama } \\
\text { Tahun } 2014 \text { dan } 2015\end{array}$} & \multirow[b]{2}{*}{ Sisa } \\
\hline & No Faktur & Note & DPP & $\begin{array}{l}\text { Pembayaran } \\
\text { PPN }\end{array}$ & $\mathrm{DPP}+\mathrm{PPN}$ & \\
\hline 22-Jun-15 & 010.002 .15 .52888844 & Cicilan 1 & $145,845,000$ & $14,584,500$ & $160,429,500$ & $4,652,455,500$ \\
\hline 13-Jul-15 & 010.002 .15 .52888849 & Cicilan 2 & $145,845,000$ & $14,584,500$ & $160,429,500$ & $4,492,026,000$ \\
\hline 19-Aug-15 & 010.002 .15 .52888861 & Cicilan 3 & $145,845,000$ & $14,584,500$ & $160,429,500$ & $4,331,596,500$ \\
\hline 07 -Sep-15 & 010.002 .15 .52888866 & Cicilan 4 & $145,845,000$ & $14,584,500$ & $160,429,500$ & $4,171,167,000$ \\
\hline 13-Oct-15 & 010.003 .15 .86606447 & Cicilan 5 & $145,845,000$ & $14,584,500$ & $160,429,500$ & $4,010,737,500$ \\
\hline 04-Nov-15 & 010.003 .15 .86606453 & Cicilan 6 & $145,845,000$ & $14,584,500$ & $160,429,500$ & $3,850,308,000$ \\
\hline 08-Dec-15 & 010.003 .15 .86606458 & \begin{tabular}{|l|} 
Cicilan 7 \\
\end{tabular} & $145,845,000$ & $14,584,500$ & $160,429,500$ & $3,689,878,500$ \\
\hline & JUMLAH & & $1,020,915,000$ & $102,091,500$ & $1,123,006,500$ & $3,689,878,500$ \\
\hline
\end{tabular}

Sumber : Data diambil dari Perusahaan (2017)

1. Mengakui Penjualan dan menjurnal dengan memasukkan PPN Keluaran

Jurnal yang benar :

Piutang Usaha-Z10 (d)Rp 4.375.000.000

PPN Keluaran (d) Rp 437.500.000

Penjualan - Z10 (k) Rp 4.812.885.000

2. Mengakui penerimaan cicilan penjualan dan menjurnal dengan memasukkan PPN Keluaran

Jurnal yang benar :

Bank Victoria KSO (d) Rp 160.429.500
Piutang Usaha - Z10 (k) Rp 145.845.000

$\begin{array}{llll}\text { PPN Keluaran } \quad(k) \quad & \text { Rp } & 14.584 .500\end{array}$

3. Perusahaan membuat kontrak perjanjian kerjasama kepada vendor.

\section{SURAT PERJANJIAN KERJASAMA PT MGM RINCIAN PEKERJAAN \\ INFRASTRUKTUR \\ SPK 006/SPK/2014JUL01 \\ Tanggal 01 Juli 2014}

Total : Rp 5.238.083.528

Jasa Kontraktor 10\% : Rp 523.808.353

DPP : Rp 5.761.891.881

PPN : Rp 576.189 .188

Total Pekerjaan $\quad$ ：Rp 6.338 .081 .069

Jurnal yang benar :

Proyek pelaksanaan-tax (d) Rp 5.761.891.881

PPN Masukan (d) Rp 576.189.188

Hutang MGM (k) Rp 6.338.081.069

4. Pada saat perusahaan membayar tagihan atas kontrak kerjasama kepada vendor tersebut.

Tabel IV - 4
Rincian Pembayaran PT MGM - Pekerjaan Infrastruktur

KSO William Mega Nusatama

\begin{tabular}{|c|c|c|c|c|c|}
\hline TANGGAL & KETI & $\begin{array}{r}\text { JUMLAH } \\
\text { DIBAYAR }\end{array}$ & $\begin{array}{c}\text { SALDO } \\
\text { HUTANG }\end{array}$ & PPH 4(2) & $\begin{array}{c}\text { JUMLAH } \\
\text { SETOR BANK }\end{array}$ \\
\hline 8-Dec-14 & Tagihan Uang Muka ke I & $750,200,000$ & $5,587,881,069$ & $27,280,000$ & $750,200,000$ \\
\hline 8-Dec-14 & Tagihan Uang Muka ke 2 & $550,000,000$ & $5,037,881,069$ & $20,000,000$ & $550,000,000$ \\
\hline 8-Dec-14 & Tagihan Uang Muka ke 3 & $573,259,456$ & $4,464,621,613$ & $20,845,798$ & $573,259,456$ \\
\hline 4-Mar-15 & Tagihan Uang Muka ke 4 & $517,416,086$ & $3,947,205,527$ & $18,815,130$ & $517,416,086$ \\
\hline 4-Mar-15 & Tagihan progress $37,886 \%$ & $677,674,407$ & $3,269,531,120$ & $24,642,706$ & $677,674,407$ \\
\hline 4-Mar-15 & Tagihan progress $60,569 \%$ & $1,078,250,088$ & $2,191,281,032$ & $39,209,094$ & $1,078,250,088$ \\
\hline 17-Mar-15 & Tagihan progress $65,56 \%$ & $237,297,731$ & $1,953,983,301$ & $8,629,008$ & $228,668,723$ \\
\hline 28-Apr-15 & Tagihan progress $66,45 \%$ & $91,029,050$ & $1,862,954,251$ & $2,482,609$ & $88,546,440$ \\
\hline 13-Jul-15 & Tagihan progress $67,478 \%$ & $91,125,750$ & $1,771,828,501$ & $3,313,664$ & $87,812,086$ \\
\hline 3-Sep-15 & Tagihan progress $69,33 \%$ & $128,251,000$ & $1,643,577,501$ & $3,497,755$ & $124,753,245$ \\
\hline 29-Oct-15 & Tagihan Progress $71,240 \%$ & $178,828,939$ & $1,464,748,562$ & $4,877,153$ & $173,951,786$ \\
\hline & JUML & $4,873,332,507$ & $1,464,748,562$ & $173,592,918$ & $4,850,532,317$ \\
\hline
\end{tabular}

Sumber : Data diambil dari perusahaan (2017)

Tanggal 13 Juli 2015 - Tagihan Progress $67,478 \%$ Pekerjaan Infrastruktur,

Jurnal yang benar :

Hutang MGM-Infrastrukt(d) Rp 91.125.750

Hutang Pajak PPh 4(2)(k) $\quad$ Rp 3.313 .664

Bank Victoria KSO (k) Rp 87.812.086 
Tabel IV - 5

Rincian Cicilan Penjualan

KSO William Mega Nusatama

Tahun 2014 dan 2015

\begin{tabular}{|c|c|c|c|c|c|c|}
\hline UNI & AMA BUYE & $\begin{array}{l}\text { HARGA UNIT } \\
\text { (DPP) }\end{array}$ & $\begin{array}{l}\text { HARGA UNIT } \\
\text { ( PPN) }\end{array}$ & $\begin{array}{c}\text { HARGA UNIT } \\
\text { (DPP + PPN) }\end{array}$ & $\begin{array}{c}\text { CICILAN } \\
\text { PENJUALAN }\end{array}$ & $\begin{array}{l}\text { PIUTANG } \\
\text { USAHA }\end{array}$ \\
\hline & & (a) & (b) & $(a+b=c)$ & (d) & $(a-e-f=g)$ \\
\hline A1 & Ety & $5,916,250,000$ & $591,625,000$ & $6,507,875,000$ & $614,125,000$ & $5,893,750,000$ \\
\hline A2 & Linda & $5,645,422,500$ & $564,542,250$ & $6,209,964,750$ & $782,999,999$ & $5,426,964,751$ \\
\hline $\mathrm{A} 3$ & Fuad & $4,819,166,000$ & $481,916,600$ & $5,301,082,600$ & $5,299,583,330$ & $1,499,270$ \\
\hline E1 & Koko & $3,811,875,000$ & $381,187,500$ & $4,193,062,500$ & $2,687,498,801$ & $1,505,563,699$ \\
\hline E2 & Lina & $3,669,375,000$ & $366,937,500$ & $4,036,312,500$ & $2,743,229,166$ & $1,293,083,334$ \\
\hline E4 & Alian Fian & $4,375,350,000$ & $437,535,000$ & $4,812,885,000$ & $1,123,006,500$ & $3,689,878,500$ \\
\hline E5 & Iskandar & $4,166,250,000$ & $416,625,000$ & $4,582,875,000$ & $1,980,590,328$ & $2,602,284,672$ \\
\hline E6 & Yosep & $4,012,500,000$ & $401,250,000$ & $4,413,750,000$ & $3,680,202,501$ & $733,547,499$ \\
\hline U2 & Yoo & $3,500,000,000$ & $350,000,000$ & $3,850,000,000$ & $3,745,993,750$ & $104,006,250$ \\
\hline U3 & Elce & $5,519,225,000$ & $551,922,500$ & $6,071,147,500$ & $5,525,599,998$ & \begin{tabular}{|l|}
$545,547,502$ \\
\end{tabular} \\
\hline $\mathrm{U} 4$ & Tjoeng & $3,427,125,000$ & $342,712,500$ & $3,769,837,500$ & $3,438,222,501$ & $331,615,000$ \\
\hline U5 & Mia & $3,284,625,000$ & $328,462,500$ & $3,613,087,500$ & $3,304,479,166$ & $308,608,335$ \\
\hline U6 & Liawa & $3,485,312,500$ & $348,531,250$ & $3,833,843,750$ & $1,846,875,001$ & $1,986,968,749$ \\
\hline & JUMLAH & $55,632,476,000$ & $5,563,247,600$ & $61,195,723,600$ & $36,772,406,040$ & $24,423,317,560$ \\
\hline
\end{tabular}

Sumber : Data diambil dari Perusahaan (2017)

\section{Membuat jurnal koreksi atas rincian cicilan penjualan.}

Tabel IV - 6

Jurnal koreksi atas penerimaan cicilan KSO William Mega Nusatama

Tahun 2014 dan 2015

\begin{tabular}{|c|l|r|r|}
\hline TANGGAL & \multicolumn{1}{|c|}{ AKUN } & \multicolumn{1}{c|}{ DEBIT } & \multicolumn{1}{|c|}{ KREDIT } \\
\hline 31-Dec-14 & Uang Muka - A1 & $614,125,000$ & \\
& Piutang Usaha - A1 & $5,893,750,000$ & \\
& PPN Keluaran & & $591,625,000$ \\
& Penjualan - A1 & $782,999,999$ & \\
\hline 31-Dec-14 & Uang Muka - A2 & $5,416,250,000$ \\
& Piutang Usaha - A2 & & \\
& PPN Keluaran & & $564,542,250$ \\
& Penjualan - A2 & $5,299,583,330$ & \\
\hline 31-Dec-14 & Uang Muka - A3 & $1,499,270$ & \\
& Piutang Usaha - A3 & & $481,916,422,500$ \\
& PPN Keluaran & & $4,819,166,000$ \\
& Penjualan - A3 & & \\
\hline
\end{tabular}

\begin{tabular}{|c|c|c|c|}
\hline 31-Dec-14 & $\begin{array}{l}\text { Uang Muka - E1 } \\
\text { Piutang Usaha - E1 } \\
\text { PPN Keluaran } \\
\text { Penjualan - E1 }\end{array}$ & $\begin{array}{l}2,687,498,801 \\
1,505,563,699\end{array}$ & $\begin{array}{r}381,187,500 \\
3,811,875,000\end{array}$ \\
\hline 31-Dec-14 & $\begin{array}{l}\text { Uang Muka - E2 } \\
\text { Piutang Usaha - E2 } \\
\text { PPN Keluaran } \\
\text { Penjualan - E2 }\end{array}$ & $\begin{array}{l}2,743,229,166 \\
1,293,083,334\end{array}$ & $\begin{array}{r}366,937,500 \\
3,669,375,000\end{array}$ \\
\hline 31-Dec-14 & $\begin{array}{l}\text { Uang Muka - E4 } \\
\text { Piutang Usaha - E4 } \\
\text { PPN Keluaran } \\
\text { Penjualan - E4 }\end{array}$ & $\begin{array}{l}1,123,006,500 \\
3,689,878,500\end{array}$ & $\begin{array}{r}437,535,000 \\
4,375,350,000\end{array}$ \\
\hline 31-Dec-14 & $\begin{array}{l}\text { Uang Muka - E5 } \\
\text { Piutang Usaha - E5 } \\
\text { PPN Keluaran } \\
\text { Penjualan - E5 }\end{array}$ & $\begin{array}{l}1,980,590,328 \\
2,602,284,672\end{array}$ & $\begin{array}{r}416,625,000 \\
4,166,250,000\end{array}$ \\
\hline 31-Dec-14 & $\begin{array}{l}\text { Uang Muka - E6 } \\
\text { Piutang Usaha - E6 } \\
\text { PPN Keluaran } \\
\text { Penjualan - E6 }\end{array}$ & $\begin{array}{r}3,680,202,501 \\
733,547,499\end{array}$ & $\begin{array}{r}401,250,000 \\
4,012,500,000\end{array}$ \\
\hline 31-Dec-14 & $\begin{array}{l}\text { Uang Muka - U2 } \\
\text { Piutang Usaha - U2 } \\
\text { PPN Keluaran } \\
\text { Penjualan - U2 }\end{array}$ & $\begin{array}{r}3,745,993,750 \\
104,006,250\end{array}$ & $\begin{array}{r}350,000,000 \\
3,500,000,000\end{array}$ \\
\hline 31-Dec-14 & $\begin{array}{l}\text { Uang Muka - U3 } \\
\text { Piutang Usaha - U3 } \\
\text { PPN Keluaran } \\
\text { Penjualan - U3 }\end{array}$ & $\begin{array}{r}5,525,599,998 \\
545,547,502\end{array}$ & $\begin{array}{r}551,922,500 \\
5,519,225,000 \\
\end{array}$ \\
\hline 31-Dec-14 & $\begin{array}{l}\text { Uang Muka - U4 } \\
\text { Piutang Usaha - U4 } \\
\text { PPN Keluaran } \\
\text { Penjualan - U4 }\end{array}$ & $\begin{array}{r}3,438,222,501 \\
331,615,000\end{array}$ & $\begin{array}{r}342,712,500 \\
3,427,125,000 \\
\end{array}$ \\
\hline 31-Dec-14 & $\begin{array}{l}\text { Uang Muka - U5 } \\
\text { Piutang Usaha - U5 } \\
\text { PPN Keluaran } \\
\text { Penjualan - U5 }\end{array}$ & $\begin{array}{r}3,304,479,166 \\
308,608,335\end{array}$ & $\begin{array}{r}328,462,500 \\
3,284,625,000\end{array}$ \\
\hline 31-Dec-14 & $\begin{array}{l}\text { Uang Muka - U6 } \\
\text { Piutang Usaha - U6 } \\
\text { PPN Keluaran } \\
\text { Penjualan - U6 }\end{array}$ & $\begin{array}{l}1,846,875,001 \\
1,986,968,749\end{array}$ & $\begin{array}{r}348,531,250 \\
3,485,312,500 \\
\end{array}$ \\
\hline & JUMLAH & $61,195,723,600$ & $61,195,723,600$ \\
\hline
\end{tabular}

Sumber : Data yang diolah oleh penulis (2017)

Tabel IV - 7

Tabel Rincian Pembayaran Vendor KSO William Mega Nusatama

Tahun 2015

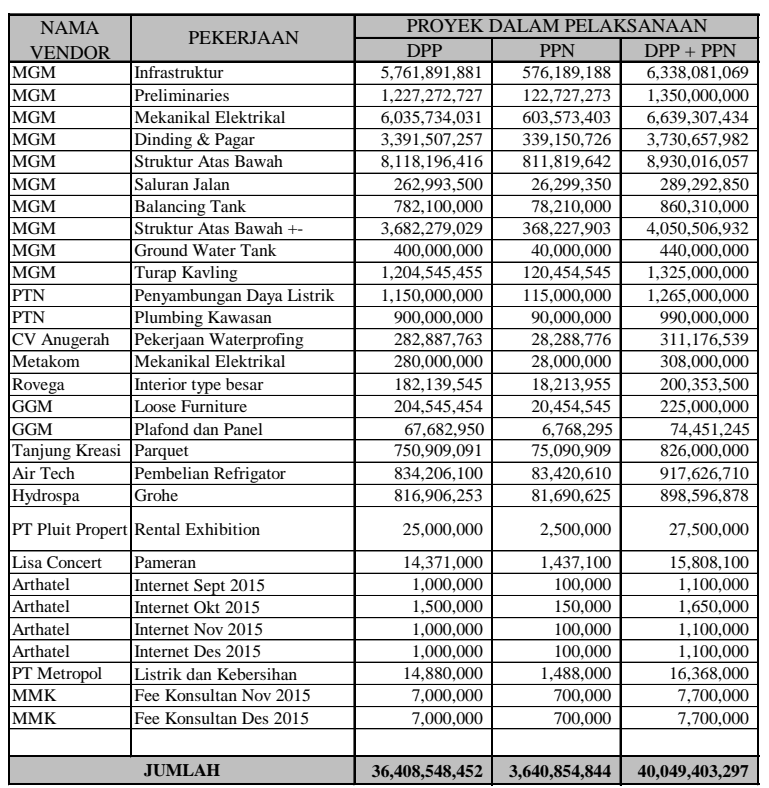

Sumber : Data yang diolah oleh penulis (2017)

6. Membuat jurnal koreksi atas rincian pembayaran vendor. 


\begin{tabular}{|c|c|c|c|}
\hline \multicolumn{4}{|c|}{$\begin{array}{c}\text { Tabel IV - } 8 \\
\text { Jurnal koreksi atas rincian pembayaran vendor } \\
\text { KSO William Mega Nusatama } \\
\text { Tahun } 2015\end{array}$} \\
\hline TANGGAL & AKUN & DEBIT & KREDIT \\
\hline 31-Dec-15 & \begin{tabular}{|l|} 
PPN Masukan \\
Proyek Dalam Pelaksanaan
\end{tabular} & $3,640,854,844$ & $3,640,854,844$ \\
\hline & JUMLAH & $3,640,854,844$ & $3,640,854,844$ \\
\hline
\end{tabular}

Sumber : Data yang diolah oleh penulis (2017)

7. Membuat jurnal koreksi atas pajak pertambahan nilai di akhir tahun 2015

Desember 2015

$\begin{array}{lrl}\text { PPN Keluaran (d) } & \text { Rp 5.563.247.600 } \\ \text { Piutang PPN Des 2015 (d)Rp } 215.631 .198 \\ \text { PPN Masukan (k) } & \text { Rp 3.640.854.844 } \\ \text { Utang PPN (k) } & \text { Rp 2.138.023.954 }\end{array}$

\section{KESIMPULAN}

1. Berdasarkan hasil analisis dan pembahasan yang telah dikemukakan sebelumnya, maka kesimpulan yang dapat disajikan adalah perusahaan telah menjadi Pengusaha Kena Pajak pada tanggal 7 Juli 2014.

2. Telah dibuktikan pula dengan dokumen administratif perpajakan seperti rincian PPN, Faktur Pajak, SSP, SPT sampai dengan bukti lapor PPN dari KPP. Namun perusahaan belum menerapkan perlakuan akuntansi pajak pertambahan nilai sehingga laporan keuangan internal perusahaan dapat dikatakan tidak akuntabel

\section{Saran}

Atas kesimpulan tersebut, maka penulis memberi saran bahwa perusahaan harus menerapkan akuntansi perpajakan terkait pajak pertambahan nilai untuk akuntabilitas didalam laporan keuangan internal yaitu :

1. Mengakui penjualan dan menjurnal dengan memasukkan PPN Keluaran

2. Mengakui penerimaan cicilan penjualan dan menjurnal dengan memasukkan PPN Keluaran

3. Membuat jurnal pada saat perusahaan membuat kontrak perjanjian kerjasama kepada vendor dan mengakui adanya PPN masukan

4. Membuat jurnal pada saat perusahaan membayar tagihan atas kontrak kerjasama kepada vendor tersebut.
5. Membuat jurnal koreksi atas rincian cicilan penjualan

6. Membuat jurnal koreksi atas rincian pembayaran vendor.

7. Membuat jurnal koreksi atas pajak pertambahan nilai di akhir tahun 2015

\section{DAFTAR PUSTAKA}

Afrika, Rizki, Betri, Icha Fajriana, 2014, Pengaruh Penetapan E-SPT Pajak Pertambahan Nilai Terhadap Kepuasan Wajib Pajak Dalam Penggunaan ESPT Pajak Pertambahan Nilai, Skripsi

Anastasia Diana dan Lilis Setiawati, 2013, Perpajakan - Teori Dan Peraturan Terkini, Yogyakarta : CV Andi

Anastasia Diana dan Lilis Setiawati, 2014, Perpajakan Indonesia, Edisi Ketiga, Yogyakarta : CV Andi

Chairil Anwar Pohan, 2016, Pedoman Lengkap Pajak Pertambahan Nilai - Teori, konsep, dan Apliasi PPN, Jakarta : PT Gramedia Pustaka Utama

Direktorat Jendral Pajak, 2013, Pajak Pertambahan Nilai, Jakarta,

Dwi Sunar Prasetyono, 2012, Buku Pintar Pajak, Yogyakarta : Laksana

Haula Rosdiana dan Edi Slamet Irianto, 2012, Pengantar Ilmu Pajak, Jakarta : PT Rajagrafindo Persada,

Hery, 2014, Akuntansi Perpajakan, Jakarta : PT Grasindo

Hery, 2017, Teori Akuntansi - Pendekatan Konsep dan Analisis, Jakarta :PT Grasindo

Ikatan Akuntan Indonesia, 2013, Modul Pelatihan Pajak Terapan Brevet A dan B Terpadu, Jakarta 
Jeni Susyanti dan Ahmad Dahlan, 2016, Perpajakan untuk Praktisi dan Akademisi, Malang : Empatdua Media,

Joseph Purwono, 2012, Perpajakan Jasa Konstruksi dan Impelementasinya, Yogyakarta : Gava Media

M, Djunaidi Ghony dan Fauzan Almanshur, 2016, Metode Penelitian Kualitatif, Yogyakarta : Ar-Ruzz Media

Mardiasmo, 2016, Perpajakan, Edisi Terbaru, Yogyakarta : CV Andi

Neneng Hartati, 2015, Pengantar Perpajakan, Bandung, CV Pustaka Setia

Oyok Abunyamin Bin H, Abas Z, 2015, Perpajakan Dasar-Dasar Perpajakan, KUP, PPh, PPN \& PPn BM, Pajak Daerah, dan Retribusi Daerah, PPSP, Pengadilan Pajak, Pengantar Perpajakan Internasional, Bandung : Mega Rancage Press,

Raja Abdurrahman, 2014, Analisis Pengaruh Pajak Pertambahan Nilai Dan Pajak Penjualan Atas Barang Mewah Terhadap Daya Beli Konsumen pada Kendaraan Bermotor, Skripsi

Rismawati Sudirman dan Antong Amiruddin, 2012, Perpajakan Pendekatan Teori dan Praktik Di Indonesia, Jakarta : Salemba Empat Dua Dunia,

Rustam Ahamadi, 2016, Metodologi Penelitian Kualitatif, Yogyakarta : Ar-Ruzz Media,

Siti Resmi, 2012, Perpajakan : Teori dan Kasus, Edisi 6 - Buku 2, Jakarta: Salemba Empat

Siti Resmi, 2016, Perpajakan : Teori dan Kasus, Edisi 9 - Buku 1, Jakarta: Salemba Empat

Sugeng Wahono, 2012, Teori Dan Aplikasi Mengurus Pajak Itu Mudah, Jakarta :
PT Elex Media Komputindo Kompas Gramedia

Sukrisno Agoes dan Estralita Trisnawati, 2013, Akuntansi Perpajakan, Edisi 3, Jakarta : Salemba Empat,

Thomas Sumarsan, 2017, Perpajakan Indonesia, Pedoman Perpajakan yang Lengkap Berdasarkan Undang-Undang Terbaru, Edisi Kelima, Jakarta : Indeks,

Tmbooks, 2013, Perpajakan - Esensi dan Aplikasi, Yogyakarta : CV Andi,

Tmbooks, 2015, Cermat Menguasai Seluk Beluk Perpajakan Indonesia, Yogyakarta : CV Andi

Waluyo, 2013, Perpajakan Indonesia, Edisi 11 buku 1, Jakarta : Salemba Empat,

Wikipedia, 2016, Akuntansi Pajak, (ONLINE), Available, https://id,m, wikipedia,org

Wiratna Sujarweni, 2015, Sistem Akuntansi, Yogyakarta : Pustaka Baru Press

Wirawan B, Ilyas dan Diaz Priantara, 2015, Akuntansi Perpajakan, Jakarta: Mitra Wacana Media

Wirawan B, Ilyas dan Rudy Suhartono, 2013, Praktikum Perpajakan-Panduan Lengkap, Teori, Pembahasan Kasus dan Penyusunan SPT, PPh Badan, PPh Orang Pribadi, PPN, PPh Potong Pungut, Edisi 2, Jakarta : In Media 